\title{
A naerobic thermophilic treatment of cattle manure in UASB reactors
}

Cattle manure was characterised after filtration through a 1-mm sieve and subsequently treated in a 9-I volume UA SB reactor made of transparent PVC at a thermophilic temperature $\left(55^{\circ} \mathrm{C}\right)$. Different $\mathrm{Hydraulic}$ Retention Times (22.5, 16, 10.6, 8.9 and 7.3 days) were employed and organic matter, total solids and metals were determined, as was the production of biogas. A fter screening, the COD of the manure subjected to anaerobic thermophilic treatment varied between values of 33,382 and $45,513 \mathrm{mgO}_{2} \mathrm{I}^{-1}$. The highest percentage of CO D removal obtained was $79.7 \%$ for an HRT of 22.5 days and there was a fraction refractory to biodegradation of $11 \%$, calculated using Chen \& H ashimoto's model.

Finally, the results obtained at a thermophilic tempera ture were compared with those obtained at a mesophilic temperature (obtained in a previous work). The reduction in COD was slightly greater under mesophilic conditions, though the main advantage of thermophilic anaerobic treatment is the faster inactivation of viruses and bacteria.

\author{
L. Castrillón \\ I. Vázquez \\ E. Marañón \\ H. Sastre
}

Department of Chemical and Environmental Engineering. Higher School of Industrial Engineering, Campus of Gijón. 33204 Gijón. University of 0 viedo, Spain

Keywords - Cattle manure, anaerobic thermophilic treatment, upflow anaerobic sludge blanket (U A SB), wmr 554-3

Corresponding author: E. Marañón. Department of Chemical
and Environmental Engineering. H igher School of Industrial
Engineering. Campus of Gijón. 33204 Gijón. U niversity of O viedo, Spain. E-mail: emara@ correo.uniovi.es

\section{Introduction}

A nimal waste, mainly manure, has been used to maintain soil fertility for many centuries. H owever, intensive animal production in recent years has resulted in high concentrations of animals in small areas, producing large amounts of waste with insufficient nearby land for its application.

A sturias is an A utonomous Community located in the $\mathrm{N}$ orth of Spain, with a large population of cattle that produces milk and meat. In general, the greatest concentration of milk-producing farms (the most problematic, since the cows are usually kept in stables) is found in the areas near the coast, where the elimination of cattle manure by means of its use as a fertiliser may lead to environmental problems. In some of these municipalities, cattle-farming concentrations in the order of 2.18 units of cattle per $\mathrm{Ha}$ of useful farmland are reached (Castrillón et al. 1999).

The manure from cattle is a material containing an abundant amount of organic matter (with values of $C O D$ of around $45,000 \mathrm{mg} \mathrm{O} \mathrm{I}^{-1}$ or higher), rich in nitrogen (fundamentally ammoniacal-N), potassium, calcium and phosphorus. It also contains variable amounts of other materials, such as heavy metals, among which the principal ones are generally Fe, M n, Zn and Cu (M arañon et al. 2001).

$W$ ithin the field of cattle manure treatment, there is a diversity of possible solutions/treatments: agricultural use of the manure, phase separation, composting, aerobic and 
anaerobic treatments, etc. (A buras et al. 1995; Boiran et al. 1996; Espona et al. 1995; Jungersen \& A hring 1994; Kanwar \& Guleri 1994; Rulkens \& H ave 1994; Shyam \& Sharma 1994; W etterauer \& Killorn 1996).

Currently, the most sought-after solution to the problem of manure waste involves the widespread application of anaerobic treatments. A naerobic digestion of manure simultaneously produces biogas, an energy source that can contribute to the self-sufficiency of the farm, as well as organo-mineral fertilisers.

A naerobic technology for industrial wastewater treatment has advanced considerably over the past decade due to the development of high-rate reactors. A lthough most of the treatability studies have been conducted under mesophilic conditions, thermophilic conditions are presumably more effective for the degradation of organic compounds and the killing of pathogens, thus minimising the risk of spreading pathogens (T urner et al. 1997).

A number of different countries use this kind of treatment at the industrial level; one of these is Denmark, where cattle manure is treated in centralised biogas plants (Danish Energy A gency, 1995). In general, the types of reactors used are stirred tanks, employing high residence times.

Various authors have studied anaerobic treatment of different farm wastes at the laboratory scale (pig manure, chicken manure, etc.), employing different types of reactors and under different operating conditions ( $M$ aibaum \& Kuehn 1999; Pagilla et al. 2000). The major difficulty for this type of treatment is to be found in the case in which the concentration of ammonium in the farm waste is too high, and may even inhibit the process. This has in fact occurred in the treatment of pig manure ( $H$ ansen et al. 1999).

A mong the high-rate reactors, the U A SB process is the most commercially successful. Hundreds of full-scale treatments plants have been installed over the past decade for the treatment of various wastewaters (Fang $\&$ W aiChung 1999).

In the case of cattle manure, the authors of the present article had previously studied its anaerobic treatment in the mesophilic range using U A SB-type reactors at laboratory scale with good results, obtaining high organic matter removal rates ( $M$ arañón et al. 2001).

The aim of the present research work was to study the anaerobic treatment of cattle manure at a thermophilic temperature and to compare this with the previously stud- ied treatment at a mesophilic temperature. The manure used in this study was produced on two farms, one with 25 cows and the other with 40 . A continuous operation was planned in order to obtain steady-state operation data and to optimise COD removal with lower hydraulic residence times. W ith the aim of comparing the results at mesophilic and thermophilic temperatures, the same HRT were used for both temperatures.

\section{Experimental}

Reactor

The reactor used at a thermophilic temperature, which had previously been used at a mesophilic temperature, was

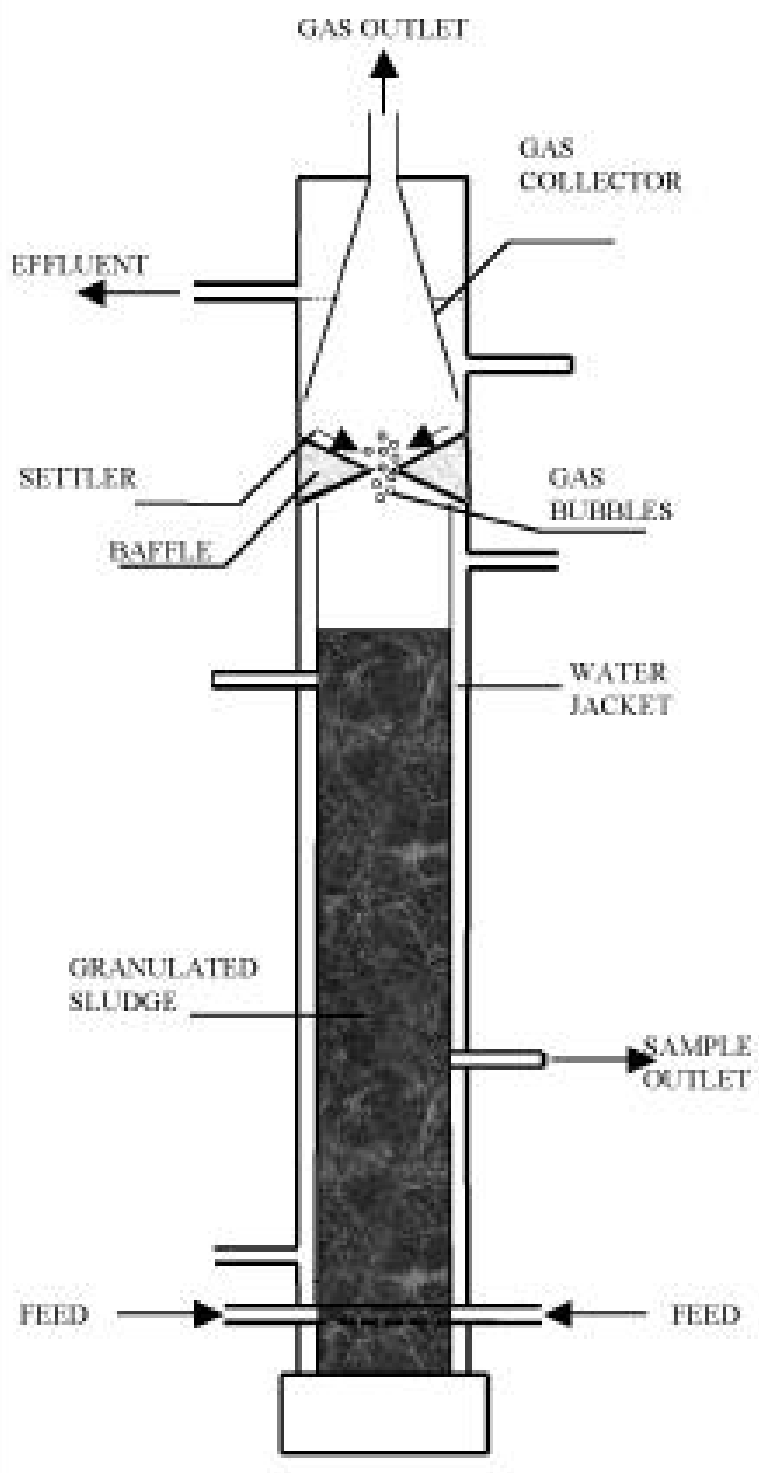

Fig. 1. UASB reactor employed in the experiments 
a UASB reactor made of transparent PV C (Fig. 1). This reactor consisted of two cylindrical sections, the lower one jacketed and separated from the upper one by a deflecting ring to facilitate phase separation. The upper part had a larger diameter and contained the gas collector, as well as outlets for the effluent, recycling and other uses. T wo sideoutlets for samples were arranged along the lower body at two different heights. The volume of the reactor up to the triphasic separator was 9 litres.

\section{A nalytical methods}

The parameters analysed in the liquid cattle manure were: COD, ammoniacal nitrogen $\left(\mathrm{N}-\mathrm{NH}_{4}{ }^{+}\right)$, phosphate $\left(\mathrm{PO}_{4}{ }^{3-}\right)$, total solids (TS), volatile total solids (VTS), volatile acidity (VA), total alkalinity (TA), gas volume, gas composition and metals. The standard methods were employed whenever applicable (A PH A , 1989).

The metals were determined by atomic absorption in a Perkin Elmer M od. 3110 spectrophotometer.

The volume of gas produced was measured using a $\mathrm{HI}$. TEC F101D thermal mass flow detector equipped with an electronic totaliser. The volumetric composition of the biogas was determined by means of a Geotechnical Instrument portable methanometer.

\section{Startup and operating mode}

A s mentioned above, the cattle manure used in this treatment came from two farms, one with 25 cows and the other with 40. $0 \mathrm{n}$ both farms, the cows are kept in the same kind of stables: a free stall barn. Samples were taken from the liquid manure cesspit, always attempting to collect these after prior agitation of the cesspit.

The samples were kept under refrigeration after collection. The cattle manure was pre-treated by filtration through a 1-mm sieve, approximately $60 \%$ of the total filtered volume passing through this sieve, the rest being retained by the filter. $W$ ith respect to solids, approximately $80 \%$ of the total solids present in the raw manure are retained by the filter, the rest passing to the filtered liquid. In some samples, it was necessary to dilute the manure before the anaerobic treatment, as shall be seen below.

Given that prior research had studied anaerobic treatment of cattle manure in the mesophilic range using two UA SB reactors ( $M$ arañón et al. 2001), the sludge from this study was used as inoculum in the start-up of the thermophilic reactor, since mesophilic populations usually contain a certain amount of thermophilic bacteria
(Schönborn et al. 1987). At start-up, diluted manure was added along with small amounts of methanol to assist the development of methanogenic bacteria (Durán et al. 1997); a period of approximately two months being needed to achieve sludge in working conditions.

The previously described parameters were determined in the manure used as feed for the reactors as well as in the effluents from the plants; the biogas generated was also characterised. Likewise, total solids and volatile solids were measured at two different points inside the reactor, with the aim of characterising the quantity of biomass inside the reactor.

\section{Results}

\section{Characterisation of manure}

Table 1 shows the average values of the composition of the influent used in the thermophilic anaerobic reactor. The COD of the majority of the samples ranged between values of around 33000 and $45000 \mathrm{mg} \mathrm{O}_{2} \mathrm{I}^{-1}$. Even though the ammoniacal nitrogen content was high (its values reaching $1100 \mathrm{mg} \mathrm{N}-\mathrm{NH}_{4}{ }^{+} \mathrm{I}^{-1}$ ), these amounts did not perturb the smooth running of the anaerobic process (Flotats et al. 1997, $\mathrm{H}$ ansen et al. 1999). The total solids content varied between values of 39.94 and $22.38 \mathrm{gl}^{-1}$, the majority of these being volatile solids.

Phosphate concentrations were always higher than 150 $\mathrm{mg} \mathrm{l}^{-1}$, being sufficient to be able to carry out the process adequately. The $\mathrm{pH}$ value was higher than 7 , ranging between 7.2 and 7.7, as can be seen in T able 1 .

Of the metals analysed ( $\mathrm{Fe}, \mathrm{Mn}, \mathrm{Cu}, \mathrm{Cr}, \mathrm{Zn}, \mathrm{Cd}$ and $\mathrm{Pb})$, the major ones present were $\mathrm{Fe}, \mathrm{Mn}, \mathrm{Zn}$ and $\mathrm{Cu}$. 0 thers appeared in very low concentrations or were unde tected, as is the case for $\mathrm{Cd}$.

\section{Performance of the UASB digester}

The U A SB digester was operated continuously for approximately one year, working with different HRT $(22.5,16$, $10.6,8.9,7.3)$. The percentage of COD removed varied between 54.8 and $79.7 \%$ for HRT of 7.3 and 22.5 days, respectively; the results obtained can be seen in Table 2 . Given the fact that for even a high HRT ( 22.5 days), the percentage of COD removed is around $79.7 \%$, an anaerobically non-biodegradable organic fraction may possibly exist. The model proposed by $\mathrm{Chen}$ and $\mathrm{H}$ ashimoto ( $\mathrm{C}$ hen $\&$ Hashimoto 1980) allows us to determine the value of this fraction. At the same time, the removal of volatile 


\begin{tabular}{|c|c|c|c|c|c|}
\hline \multirow[b]{2}{*}{ Parameter } & \multicolumn{5}{|c|}{ HRT (days) } \\
\hline & 22.5 & 16 & 10.6 & 8.9 & 7.3 \\
\hline $\mathrm{pH}$ & 7.3 & 7.2 & 7.2 & 7.7 & 7.3 \\
\hline $\mathrm{N}-\mathrm{N} \mathrm{H}_{4}{ }^{+}\left(\mathrm{mg} \mathrm{l}^{-1}\right)$ & 1082 & 1008 & 653 & 964 & 783 \\
\hline $\mathrm{TA}\left(\mathrm{mg} \mathrm{CaCO}{ }_{3} \mathrm{I}^{-1}\right)$ & 7454 & 6617 & 4767 & 7582 & 6968 \\
\hline VA (mg $\mathrm{CH}_{3} \mathrm{COOH \textrm {H } ^ { - 1 } )}$ & 2749 & 4107 & 2997 & 3077 & 1714 \\
\hline $\operatorname{COD}\left(\mathrm{mg} \mathrm{O}_{2} \mathrm{I}^{-1}\right)$ & 37527 & 45513 & 33382 & 37421 & 37034 \\
\hline Total solids $\left(\mathrm{g} \mathrm{|}^{-1}\right)$ & 29.16 & 31.85 & 22.38 & 28.07 & 39.94 \\
\hline Inorganic solids $\left(\mathrm{g} \mathrm{I}^{-1}\right)$ & 11.09 & 9.98 & 7.10 & 9.69 & 16.12 \\
\hline Volatile solids $\left(\mathrm{g} \mathrm{I}^{-1}\right)$ & 18.07 & 21.87 & 15.28 & 18.38 & 23.82 \\
\hline$\%$ Volatile solids & 62.0 & 68.7 & 68.3 & 65.5 & 59.6 \\
\hline $\mathrm{Fe}\left(\mathrm{mg} \mathrm{I}^{-1}\right)$ & 50.87 & 80.21 & 60.43 & 79.33 & 71.52 \\
\hline $\mathrm{Zn}\left(\mathrm{mg} \mathrm{l}^{-1}\right)$ & 4.96 & 3.25 & 13.40 & 21.50 & 17.32 \\
\hline $\mathrm{Cu}\left(\mathrm{mg} \mathrm{l}^{-1}\right)$ & 1.74 & 3.14 & 2.08 & 2.17 & 1.94 \\
\hline $\mathrm{Pb}\left(\mathrm{mg} \mathrm{l}^{-1}\right)$ & 0.26 & 0.39 & 0.39 & 0.36 & 0.32 \\
\hline $\mathrm{Cr}\left(\mathrm{mg} \mathrm{l}^{-1}\right)$ & 0.08 & 0.31 & 0.25 & 0.28 & 0.28 \\
\hline $\mathrm{Cd}\left(\mathrm{mg} \mathrm{I}^{-1}\right)$ & n.d. & n.d. & n.d. & n.d. & n.d. \\
\hline
\end{tabular}

fatty acids decreases with decreasing $H R T$, good correlations existing with respect to the COD. A lthough in some cases the total volatile acidity in the effluent exceeds the value of $500 \mathrm{mg} \mathrm{l}^{-1}$, the fact that the values of alkalinity were high ( $T$ able 3 ) leads to this acidity being neutralised without presenting problems of acidification in the reactor.

For values equal to or less than 10.6 days, it was not possible to work with manure that presented COD higher than $40000 \mathrm{mg} \mathrm{O}_{2} \mathrm{I}^{-1}$, since flotation of the sludge took place within the reactor. It was therefore necessary to dilute the manure until the values of the concentrations were lower than this value. This circumstance was not observed when working in the mesophilic range ( $M$ arañón et al. 2001).

This situation might perhaps be solved by recirculating the liquid effluent, which would lead to dilution of the influent. H owever, this recirculation was not carried out, since the high values of $\mathrm{pH}$ presented by the effluent (between 8.0 and 8.3, as can be seen in Table 3) would entail the addition of hydrochloric acid so as to decrease the $\mathrm{pH}$.

Table 2. COD and VA removal for the different HRT and OLR (mean values)

\begin{tabular}{lcccc}
\hline $\begin{array}{l}\text { HRT } \\
\text { (days) }\end{array}$ & $\begin{array}{c}\text { COD } \\
\text { Influent, } \mathrm{mg} \mathrm{l}^{-1}\end{array}$ & $\begin{array}{c}\text { O LR } \\
\mathrm{kg} \mathrm{COD} \mathrm{m}^{-3} \mathrm{~d}^{-1}\end{array}$ & $\begin{array}{c}\text { \% COD } \\
\text { removed }\end{array}$ & $\begin{array}{c}\text { \% VA } \\
\text { removed }\end{array}$ \\
\hline 22.5 & 37527 & 1.67 & 79.7 & 86.7 \\
16 & 45513 & 2.84 & 74.9 & 84.7 \\
10.6 & 33382 & 3.15 & 68.1 & 83.8 \\
8.9 & 37421 & 4.16 & 61.2 & 78.8 \\
7.3 & 37034 & 5.06 & 54.8 & 54.2 \\
\hline
\end{tabular}

A s mentioned above, determination of the content of total solids (TS) and volatile solids (VS) was carried out both in the filtered manure (in some cases diluted) used as influent for the reactor, as well as in the effluents generated. Likewise, the concentration of total and volatile solids inside the reactor was also carried out, employing the two samples outlets located at different heights. Due to the difficulties encountered in filtering the manure through a $0.45 \mu \mathrm{m}$ filter, determination of suspended volatile solids, considered to be indicative of the microbial concentration, was not carried out. T able 4 presents the results obtained.

To determine the solids inside the reactor, weekly samples were taken in the order of $100 \mathrm{ml}$ at the lower exit and $75 \mathrm{ml}$ at the upper exit, which allowed the growth of the biomass throughout the reactor to be controlled. This operation served at the same time to carry out purging of the sludge. When the concentration of solids was very high, the volume of sludge to be purged at the lower sampling outlet was increased, thus impeding excessive accumulation of inorganic solids inside the reactor.

A s can be observed, the concentration of total solids

Table 3. Values of total alkalinity and $\mathrm{pH}$ of the effluent for each HRT

\begin{tabular}{lrrrrr}
\hline HRT (days) & 22.5 & 16 & 10.6 & 8.9 & 7.3 \\
\hline$\left.\begin{array}{l}\text { TA influent } \\
\text { (mgCaCO }\end{array}\right|^{-1}$ ) & 7454 & 6617 & 4767 & 7582 & 6968 \\
$\begin{array}{l}\text { TA effluent } \\
\text { (mg CaCO }\end{array}{ }^{-1}$ ) & 3783 & 4877 & 4184 & 5671 & 5526 \\
pH effluent & 8.2 & 8.3 & 8.1 & 8.0 & 8.0 \\
\hline
\end{tabular}


Table 4. A verage concentration of the solids in the influent manure, the effluent and inside the reactor for the different HRT (mean values)

\begin{tabular}{|c|c|c|c|c|c|}
\hline $\begin{array}{l}\text { HRT } \\
\text { (days) }\end{array}$ & $\begin{array}{l}\text { Influent } \\
\text { TS, g I-1 } \\
\text { (\%VS) }\end{array}$ & $\begin{array}{c}\text { Reactor } \\
\text { Lower sampling outlet } \\
\text { TS, } \mathrm{g} \mathrm{I}^{-1}(\% \mathrm{VS})\end{array}$ & $\begin{array}{c}\text { Reactor } \\
\text { Upper sampling outlet } \\
\text { TS, } \mathrm{g} \mathrm{I}^{-1}(\% \mathrm{VS})\end{array}$ & $\begin{array}{c}\text { Effluent } \\
\text { TS, } \mathrm{g} \mathrm{I}^{-1}(\% \mathrm{VS})\end{array}$ & $\begin{array}{l}\text { Ratio } \\
\text { VS Effluent } \\
\text { VS Influent }\end{array}$ \\
\hline 22.5 & $\begin{array}{l}29.16 \\
(62.0)\end{array}$ & $\begin{array}{c}47.94 \\
(55.7)\end{array}$ & $\begin{array}{c}18.00 \\
(55.7)\end{array}$ & $\begin{array}{l}11.91 \\
(49.8)\end{array}$ & 0.31 \\
\hline 16 & $\begin{array}{c}31.85 \\
(68.7)\end{array}$ & $\begin{array}{l}42.60 \\
(60.1)\end{array}$ & $\begin{array}{l}43.50 \\
(60.9)\end{array}$ & $\begin{array}{c}15.37 \\
(56.7)\end{array}$ & 0.36 \\
\hline 10.6 & $\begin{array}{c}22.38 \\
(68.3)\end{array}$ & $\begin{array}{r}40.50 \\
(59.9)\end{array}$ & $\begin{array}{l}28.90 \\
(61.8)\end{array}$ & $\begin{array}{l}10.98 \\
(67.2)\end{array}$ & 0.42 \\
\hline 8.9 & $\begin{array}{l}28.066 \\
(65.5)\end{array}$ & $\begin{array}{r}43.57 \\
(60.7)\end{array}$ & $\begin{array}{c}33.40 \\
(61.4)\end{array}$ & $\begin{array}{l}14.66 \\
(55.4)\end{array}$ & 0.43 \\
\hline 7.3 & $\begin{array}{c}39.94 \\
(59.6)\end{array}$ & $\begin{array}{r}45.70 \\
(55.6)\end{array}$ & $\begin{array}{r}32.37 \\
(52.8)\end{array}$ & $\begin{array}{c}22.69 \\
(54.3)\end{array}$ & 0.52 \\
\hline
\end{tabular}

decreases with the height inside the reactor, with the exception of the 16-day HRT, in which this concentration presents very similar values. Increasing the HRT diminishes the content in volatile solids in the effluent.

Table 5 shows the metals content in both the influent and the effluent of the reactor. It can be seen that the metal found in the highest proportion is iron, followed by $\mathrm{Zn}, \mathrm{Mn}$ and $\mathrm{Cu}$. W e can also see that after anaerobic treatment, a reduction in the metals content is produced, due on the one hand to their precipitation as sulphides or hydroxides, and on the other, to adsorption processes of the metals in the sludge (A rtola et al. 1997). The metals removed to the greatest extent are those found at higher concentrations. No relationship was observed between the percentage removal and the operating $\mathrm{HRT}$.

In anaerobic processes, the microorganisms consume organic matter and transform this into a gas composed mainly of methane and carbon dioxide. The values of maximum production attained were $0.30 \mathrm{~m}^{3} \mathrm{CH}_{4} \mathrm{Kg}^{-1} \mathrm{COD}$ removed for the lowest $H R T$, close to the theoretical value of $0.35 \mathrm{~m}^{3} \mathrm{CH}_{4} \mathrm{Kg}^{-1} \mathrm{COD}$. The percentage in volume of methane in the biogas varied between $67.7 \%$ and $56.0 \%$.

Kinetic model

If the ratio $S / S o$ (concentrations of effluent and influent, expressed as COD) is plotted against the HRT (Fig. 2), a concordance for all points can be observed (regression values of 0.998). The $\mathrm{Chen}$ and $\mathrm{H}$ ashimoto model ( $\mathrm{ST}=\mathrm{R}$ $+(1-R) K / q m m-1+K, q=H R T)$ was applied to the experimental data with the following results for the different parameters:

Kinetic constant, $\mathrm{K}=0.595$

Specific growth rate, $\mathrm{mm}=0.266$ day- 1

Refractory fraction, $R=0.11$

Table 5. A verage metals content in the influents and the effluents for the different HRT

\begin{tabular}{|c|c|c|c|c|c|c|c|c|}
\hline HRT (days) & M etal (mg l-1) & $\mathrm{Fe}$ & $\mathrm{Mn}$ & $\mathrm{Zn}$ & $\mathrm{Cu}$ & $\mathrm{Pb}$ & $\mathrm{Cr}$ & $\mathrm{Cd}$ \\
\hline \multirow[t]{3}{*}{22,5} & Influent & 50.87 & 7.70 & 4.96 & 1.74 & 0.26 & n.d. & n.d. \\
\hline & Effluent & 18.32 & 1.98 & 1.38 & 0.68 & 0.18 & n.d. & n.d. \\
\hline & $\%$ Removal & 64.1 & 74.2 & 71.2 & 60.8 & 30.7 & - & - \\
\hline \multirow[t]{3}{*}{16} & Influent & 80.21 & 8.54 & 3.25 & 3.14 & 0.39 & 0.31 & n.d. \\
\hline & Effluent & 36.76 & 4.44 & 1.56 & 1.92 & 0.22 & 0.21 & n.d. \\
\hline & $\%$ Removal & 50.4 & 48.0 & 51.8 & 38.7 & 44.2 & 32.2 & - \\
\hline \multirow[t]{3}{*}{10.6} & Influent & 60.43 & 9.60 & 13.40 & 2.08 & 0.39 & 0.25 & n.d. \\
\hline & Effluent & 27.93 & 4.25 & 7.37 & 1.19 & 0.24 & 0.14 & n.d. \\
\hline & \% Removal & 53.8 & 35.6 & 45.0 & 43.0 & 39.0 & 42.4 & - \\
\hline \multirow[t]{3}{*}{8.9} & Influent & 79.33 & 1.50 & 21.50 & 2.17 & 0.36 & 0.28 & n.d. \\
\hline & Effluent & 30.04 & 1.31 & 7.99 & 1.30 & 0.17 & 0.13 & n.d. \\
\hline & \% Removal & 62.1 & 12.9 & 62.8 & 39.9 & 72.8 & 54.3 & - \\
\hline \multirow[t]{3}{*}{7.3} & Influent & 71.52 & 2.84 & 17.32 & 1.94 & 0.32 & 0.28 & n.d. \\
\hline & Effluent & 32.87 & 2.04 & 5.83 & 0.97 & 0.20 & 0.24 & n.d. \\
\hline & $\%$ Removal & 54.0 & 28.3 & 66.3 & 49.9 & 37.5 & 15.0 & - \\
\hline
\end{tabular}

n.d. not detected 


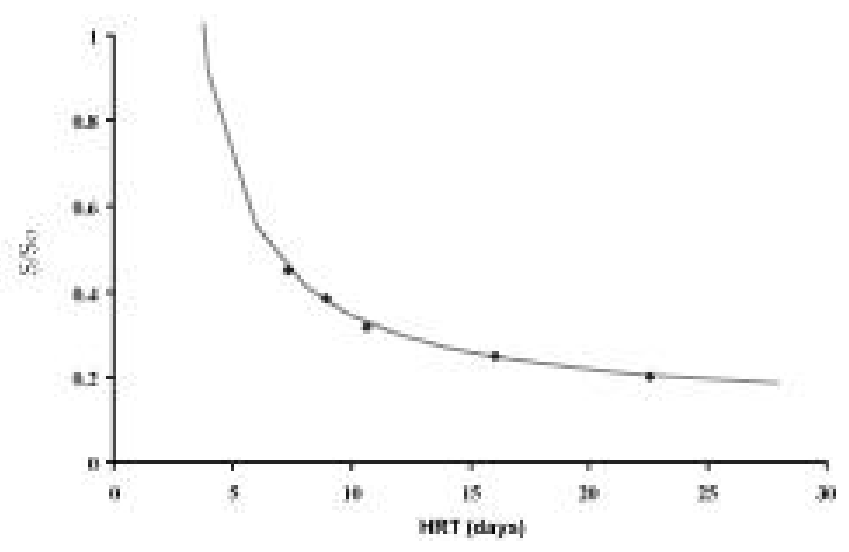

Fig. 2. Ratio CO D effluent/ influent versus HRT

The fraction refractory to biodegradation $(R)$ was found to be about $11 \%$, which means that at a thermophilic temperature a fraction that is refractory to anaerobic treatment exists in cattle manure that is mainly made up of lignocellulosic material not digested by the animal. A ccording to this values, if we consider the highest COD removal obtained $(79.7 \%)$, there is still a fraction of about $9 \%$ that may possibly be removed by operating at higher HRT.

\section{Comparison between mesophilic and thermophilic anaerobic digestion}

To compare anaerobic treatment at mesophilic (more detailed data can be found elsewhere, $M$ arañon et al. 2001) and thermophilic temperatures, the percentage of COD removed and the content of material that was refractory to degradation were analysed. The fact that, as mentioned above, it was not possible to work in the thermophilic range with COD higher than $40000 \mathrm{mg} \mathrm{O}_{2} \mathrm{~L}^{-1}$ for HRT of 10.6 days or less meant that the organic loading rates used in the thermophilic range were lower than those used in the mesophilic range, even though the same H RT had been used in both temperature ranges. This consequently impeded the comparison of the removal capacity achieved as a function of the HRT. In the comparative study, the percentage removal achieved was therefore studied as a function of the $O$ rganic Loading Rate (OLR) of the influent.

Fig. 3 presents the average percentages of COD removal for both types of digestion as a function of the OLR. As can be observed, the values are generally slightly lower at the thermophilic temperature. Thus, from this point of view, the use of thermophilic treatment is not advantageous in the case of anaerobic treatment of cattle waste.

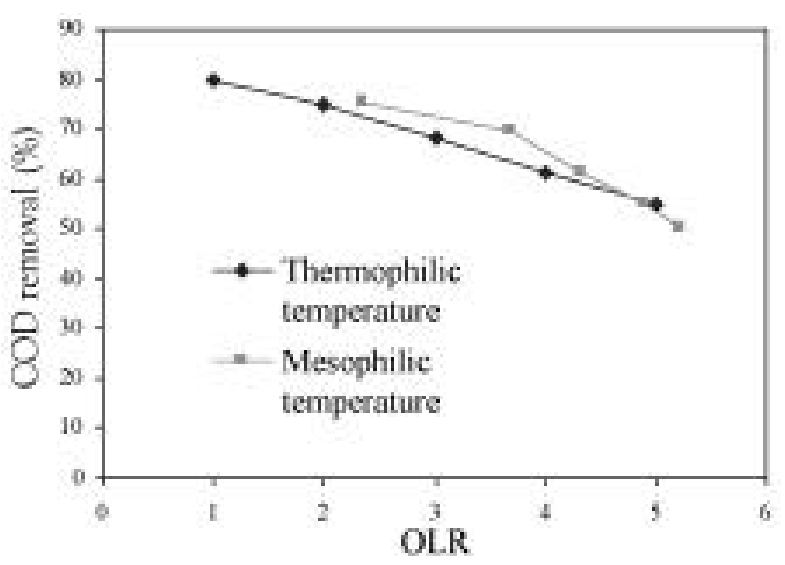

Fig. 3. Percentages of COD removal versus $O L R$

H owever, when faced with the choice of one temperature range or the other, other factors must be considered, amongst these the possible inactivation of bacteria and viral pathogens, for which the results are more positive in the case of working at a thermophilic temperature (T urner $\&$ Burton 1997).

The percentage of material refractory to anaerobic biological degradation coincides for both temperature ranges; thus the amount of organic matter that may be removed would be similar.

\section{Conclusions}

A naerobic treatment may be applied to the liquid cattle manure studied, resulting in a high percentage of COD removal. H owever, the COD level of the effluent is still high. This fact, together with that of the high amounts of ammoniacal nitrogen present, points to the need to use this method in combination with others: aerobic and/or physico-chemical methods.

The fraction that is refractory to biodegradation $(R)$ was determined to be about $11 \%$.

The percentages of COD removal achieved in the thermophilic range are generally slightly lower than those obtained in the mesophilic range. If we solely take into consideration this parameter, anaerobic treatment in the thermophilic range will therefore not be advantageous, as it consumes more energy to heat the reactor. However, thermophilic treatment achieves a greater removal of the pathogenic microorganisms that may be present in the manure. This could also be achieved by subjecting the manure to pasteurisation prior to anaerobic treatment. 


\section{References}

A buras, R., Hammad, M., A bu-Reesh, I. Hiary, S. \& Q ousous, S. (1995) Construction and operation of a demonstration biogas plant, problems and prospects. Bioresource Technology, 53, 101-104.

A PHA , A W W A, W PCF (1989) Standard M ethods for the Examination of Water and Wastewater, 17th ed. Public Health A ssociation, Washington, D.C.

A rtola, A .; Balaguer, M.D. and Rigola, M . (1997) H eavy metal binding to anaerobic sludge. $W$ at. Res. 31, 5, 997-1004.

Boiran, B., Couton, Y. \& Germon, J. (1996) N itrification and denitrification of liquid lagoon piggery waste in a biofilm infiltration-percolation aerated system (BIPA S) reactor. Bioresource T echnology, 55, 63-77.

Castrillón, L., M arañón, E., Sastre, H., González, J. M., Generación de purines en A sturias: volumen y composición. (Cattle manure generation in A sturias: volume and composition) VI Congreso de Ingeniería A mbiental PRO M A' 99. Bilbao, 23-25 February 1999.

Chen, Y.\& Hashimoto, A . (1980) Substrate utilization kinetic model for biological treatment processes. Biotech. Bioeng. 22, 2081-95.

Danish Energy A gency (1995) Progress report on the economy of Centralized Biogas Plants, Copenhagen.

Durán, M.M., Álvarez, P., Romero, F. (1997) Depuración anaerobia de purines de cerdo a 25ㅇ: influencia del soporte de inmovilización (A naerobic treatment of swine waste at $25^{\circ} \mathrm{C}$ : influence of inmoviliza tion support). Tecnología del A gua, 165, 49-57.

Espona, J., T uret, J., V iver, J. (1995) A ireación forzada del residuo de ganado porcino en régimen semicontinuo (Forced aeration of pig manure in a semi-continuous system). Tecnología del A gua, 141, 41-45.

Fang, H.H.P.\& W ai-Chung Chung, D. (1999) A naerobic treatment of proteinaceous wastewater under mesophilic and thermophilic conditions. Wat. Sci. Tech. 40, 1, 77-84.

Flotats, X., Bonmatí, A ., Campos, E., A ntúnez, M. Codigestión anaerobia termofílica de purines de cerdo y lodos de planta depuradora de aguas residuales, (A naerobic thermophilic co-digestion of pig manure and sewage sludge from municipal wastewater plants), $V$ Congreso de Ingeniería A mbiental PRO M A ' 97. Bilbao, 11-12 M arch 1997.

Hansen K. H., A ngelidaki, I and A hring, B.K. (1999) Improving thermophilic anaerobic digestion of swine manure. Wat. Res. 8, 1805-1810.

Jungersen, G. \& A hring, B. (1994) A naerobic digestion of liquefied cow manure pretreated by catalytic liquefaction. W at. Sci. T ech. 30, 12, 385-394.

Kanwar, S. \& Guleri, R. (1994) Performance evaluation of a family-size, rubber-balloon biogas plant under hilly conditions. Bioresource Technology. 50, 119-121.

M aibaum, C. \& Kuehn, V. (1999) Thermophilic and mesophilic operation of an anaerobic treatment of chicken slurry together with organic residual substances. W at. Sci. T ech. 40, 1, 231-236.

M arañón, E. Castrillón, L., Vazquez, I, Sastre, H . (2001) The influence of $H$ idraulic Residence T ime on the treatment of cattle manure in UA SB reactors. W aste $M$ anagement $\&$ Research $19,5,436-441$.

Pagilla, K. R., Kim, H . and Cheunbarn, T. (2000) A erobic thermophilic and anaerobic mesophilic treatment of swine waste. $W$ at. Res. 34,10 , 2742-2753.

Rulkens, W . \& H ave, P. J. W . (1994) Central processing of pig manure in the $N$ etherlands. W at. Sci. Tech. 30, 7, 157-165.

Schönborn, W ., Rehm, H -J, Reed, G. (1986) Biotechnology. Vol 8, VCH.

Shyam, M. \& Sharma, P. (1994) Solid state anaerobic digestion of cattle dung and agro-residues in small-capacity field digesters, Bioresource Technology, 48, 203-207.

Turner, C . \& Burton, C.H . (1987) The inactivation of viruses in pig slurries: A review, Bioresource Technology, 61, 9-20.

Wetterauer, D. \& Killorn, R. (1996) Composting animal manure with municipal yard trimmings. Biocycle, 0 ctober, 54-57. 